Provided for non-commercial research and education use. Not for reproduction, distribution or commercial use.

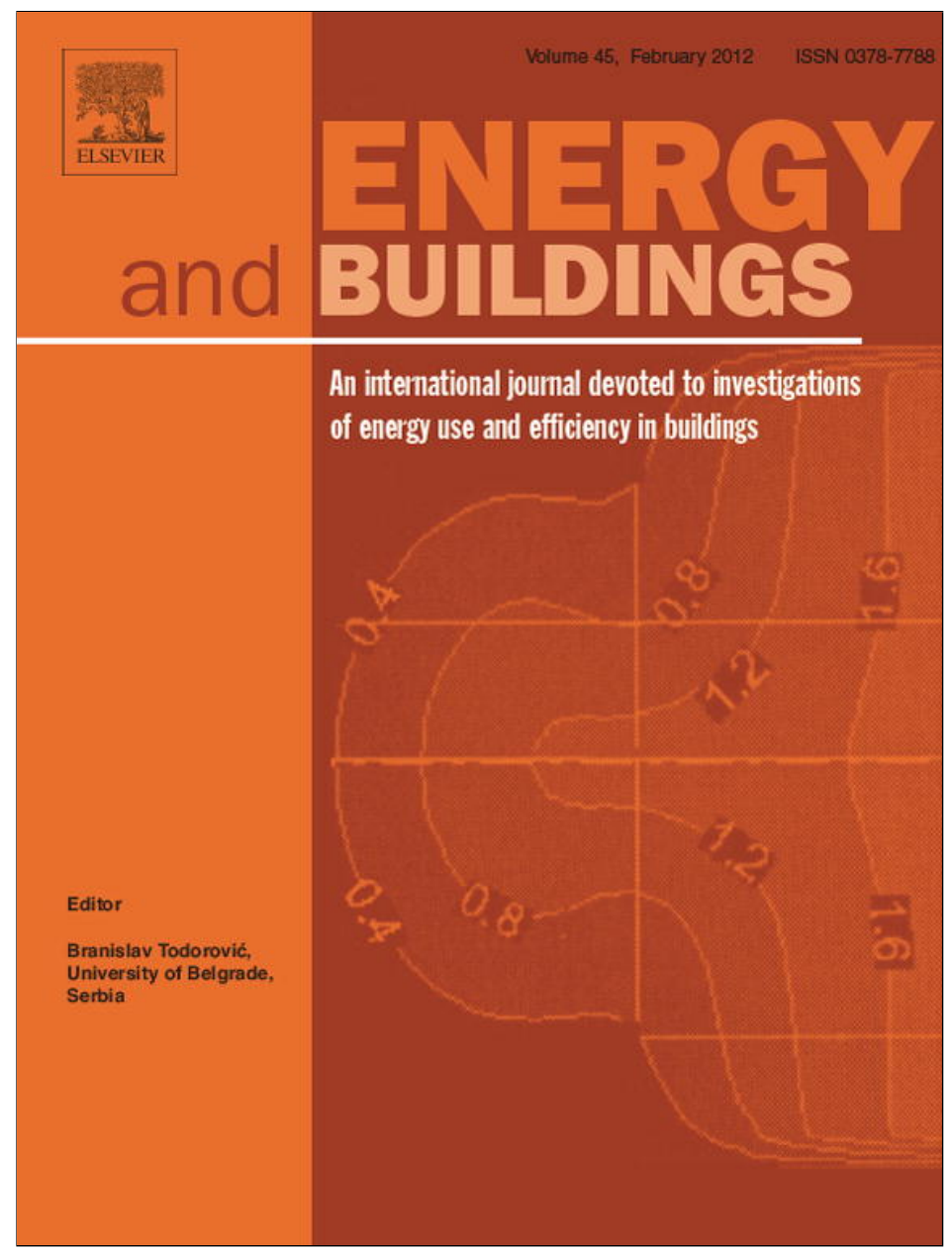

This article appeared in a journal published by Elsevier. The attached copy is furnished to the author for internal non-commercial research and education use, including for instruction at the authors institution and sharing with colleagues.

Other uses, including reproduction and distribution, or selling or licensing copies, or posting to personal, institutional or third party websites are prohibited.

In most cases authors are permitted to post their version of the article (e.g. in Word or Tex form) to their personal website or institutional repository. Authors requiring further information regarding Elsevier's archiving and manuscript policies are encouraged to visit:

http://www.elsevier.com/copyright 


\title{
A contribution to the thermal insulation performance characterization of corn cob particleboards
}

\author{
Anabela Paiva $^{\mathrm{a}, \mathrm{b}}$, Sandra Pereira ${ }^{\mathrm{a}, \mathrm{b}}$, Ana Sá $^{\mathrm{a}, \mathrm{b}}$, Daniel Cruz ${ }^{\mathrm{a}}$, Humberto Varum ${ }^{\mathrm{c}, *}$, Jorge Pinto ${ }^{\mathrm{a}, \mathrm{d}}$ \\ a ECT, Dep. de Engenharias, Universidade de Trás-os-Montes e Alto Douro, Portugal \\ ${ }^{\mathrm{b}} \mathrm{C}-\mathrm{MADE}$, Universidade da Beira Interior, Portugal \\ ${ }^{\mathrm{c}}$ Dep. de Engenharia Civil, Universidade de Aveiro, Portugal \\ d Laboratório Associado I3N, Aveiro, Portugal
}

\section{A R T I C L E I N F O}

\section{Article history:}

Received 2 September 2011

Received in revised form 9 November 2011

Accepted 14 November 2011

\section{Keywords:}

Corn cob

Particleboard

Thermal insulation

Agricultural waste materials

\begin{abstract}
A B S T R A C T
An alternative expedite experimental set-up is proposed to evaluate the thermal insulation performance of corn cob particleboards. Testing in situ thermal insulation performance under real thermal and hygrometric conditions, using more realistic sample dimensions, testing simultaneously several samples and monitoring continuously for several days the thermal behavior of a product are some advantages of this proposed technique. Therefore, it has shown to be accurate and versatile. Through this experimental methodology, a parametric thermal insulation study of the corn cob particleboard in which the impact of its thickness on its thermal insulation performance was also possible to perform.
\end{abstract}

(C) 2011 Elsevier B.V. All rights reserved.

\section{Introduction}

The continuous search for better sustainable and economic processed solutions has been receiving the attention of a broad research community worldwide. The resulting solutions can be therefore adapted by the industry leading to a more sustainable society. The building industry is not immune to this reality and huge efforts have been done in order to find alternative sustainable building materials and low technology methods which result in a more sustainable and affordable construction, complemented with the comfort standards required nowadays. $\mathrm{CO}_{2}$ emissions to the atmosphere, energy and water consumptions are some parameters that have significant impact in this equation. Reusing, opting for green building materials (which must be renewable, local, and abundant), retrofitting, choosing low technology methods and techniques are some practices that have given good results in this context.

Several authors [1-5] have already proposed using different agricultural products such as bagasse, cereal, straw, corn stalk, corn cob, cotton stalks, kenaf, rice husks, rice, straw, sunflower hulls and stalks, banana stalks, coconut coir, bamboo, durian peel and palm leaves oil, among others, for product processing such as particleboard, hardboard and fiber board, and focusing on their thermal insulation capacity. Other authors have been studying the technical potential of using other types of residue such as newspaper

\footnotetext{
* Corresponding author. Tel.: +351 234370 938; fax: +351 234370094 .

E-mail address: hvarum@ua.pt (H. Varum).
}

[6], honeycomb [7] or polymeric wastes [8] in the processing of different building components.

Among the above identified agricultural products corn cob has an additional advantage when thought in terms of possible application for alternative processed products because it does not collide with the worldwide food stock and it is generally considered as agricultural waste. Recent research works [9-14] have given particular emphasis to the application of corn cob in the industry.

In the Portuguese agricultural context, the recent figures [15] indicate that there is a decreasing tendency of the corn plantation intensity in the last few years. However, this activity is still relevant in the Portuguese agricultural panorama. The corn plantation is mainly processed in the north and centre regions of Portugal mainland. Corn and corn stalk have different uses but the corn cob is in general treated as agricultural waste which it is necessary to burn. Unfortunately, this option does not contribute to a better environmentally friendly world. Finding fields in which it is possible to use corn cob can help solve this problem and also stimulate small industrial activities using low technology methods which may contribute simultaneously to the social economical development of certain interior regions of the north of Portugal. The building industry is one of those fields in which the corn cob can have an important role as an alternative sustainable building material. Meanwhile, a set of ancient Portuguese buildings located in the north of Portugal were recently reported to present corn cobs in their external walls [9]. These facts have inspired us to study a corn cob particleboard able to be a sustainable and affordable alternative product which may be applied in different building 


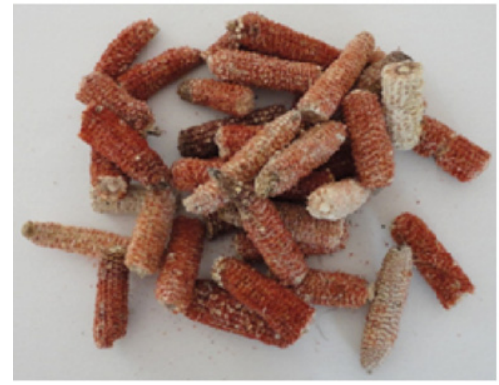

a) Corn cob

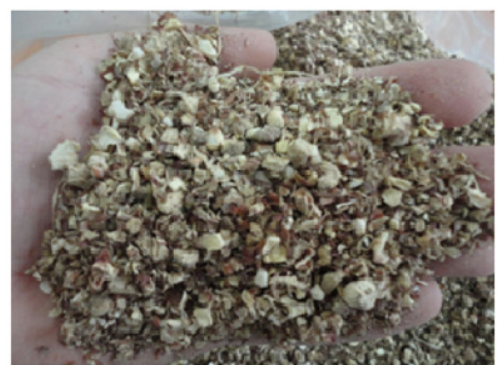

b) Corn cob particles

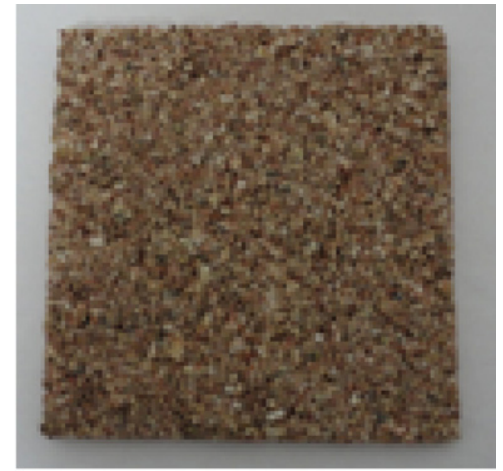

c) Panel

Fig. 1. Corn cob particleboard.

applications such as a thermal insulation product, an acoustic insulation product, a lightweight partition wall, a ceiling coating, and indoor doors, among others. In these suggested possible building applications the thermal insulation performance of the corn cob particleboard is relevant and, therefore, it is important to evaluate its thermal transmission coefficient and thermal conductivity. The main objective of this paper consists precisely in proposing an alternative expedite experimental set-up able to evaluate the thermal insulation performance of the corn cob particleboard which is still under research and is basically manufactured.

This paper is structured as follows: firstly, the corn cob particleboard is briefly put in context; secondly, the proposed alternative expedite experimental set-up is presented in which the inherent facility, the equipment and the sample preparation are described in detail; thirdly, the obtained experimental results are presented and the thermal transmission coefficient of four different thicknesses of corn cob particleboards are quantified; fifthly, the potential of the proposed alternative expedite experimental set-up is discussed, as well as the obtained results; finally, the main conclusions of this research work are drawn.

\section{Context}

As it was mentioned a corn cob particleboard has been under research by this team in order to assess it as a possible alternative sustainable solution for different building applications. A simple manufacturing process consisting in binding corn cob particles with wood glue was adopted. This process includes four main stages which are, respectively: mixing up of the components (i.e. corn cob particles and wood glue); molding; curing (which is natural) and unmolding. The resulting corn cob particleboard has been tested and, so far, some of the physical (e.g. density, water resistance, fire resistance, durability, acoustic insulation capacity) and mechanical (e.g. compression strength, bending strength and impact resistance) properties obtained, and its sustainability performance suggest adequacy of this product for the above identified building applications in an environmentally friendly way. This engineered sustainable product is presented in Fig. 1.

\section{Proposed experimental set-up}

In [12], a specific experimental device was designed by Dowling and Mathia. They proposed to compare the thermal insulating capacity of materials. However, this device is limited in terms of material size sample. On the other hand, Pinto et al. applied the thermography to compare the thermal insulation performance of corn cob and extruded polystyrene (XPS) [9], but this technique is not able to evaluate the thermal transmission coefficient $(U)$ or the thermal conductivity $(\lambda)$ of materials. Therefore, an alternative experimental procedure to evaluate the corn cob particleboards thermal insulation performance is proposed in this research work which is based on the approach described in ISO 9869 [16]. The facilities, the equipment and the sample preparation are crucial for the success of the proposed experimental set-up.

\subsection{Facility}

A confined room was used as an alternative expedite solution of a testing thermal cell. The room has to have at least a door and a window and to be as tight as possible. The window has to be preferentially oriented to the north direction in order to avoid the direct sunshine incidence, and also protected from the outside to avoid the sample wetting by the rain which may change its moister content and consequently its thermal properties.

In the Portuguese context and, in particular, in the north region of this country, it is convenient to perform this test during the winter or the summer because it is easy to ensure the desirable uniform high thermal gradient between indoor and outdoor. A uniform high thermal gradient between indoor and outdoor is desirable because it is the ideal condition to allow a significant heat flow across the material. During the winter, this condition can be achieved by using a simple domestic heating device placed indoor that enables a constant temperature inside the room higher than the external temperature. In contrast, during the summer, an air conditioner can keep the room constantly cool. A room sized $4.00 \mathrm{~m} \times 3.00 \mathrm{~m} \times 2.54 \mathrm{~m}$ (length $\times$ width $\times$ height) was used, as Fig. 2 schematically illustrates. In this case, the windows are oriented to the northeast direction, they are protected from the rain, the test was performed during the end of the winter of 2011 (i.e. from $22 / 02 / 2011$ to $22 / 03 / 2011$ ) and under dried climate conditions.

\subsection{Equipment}

A heat flux meter system was adopted as well as two thermo hygrometric devices and a domestic heat device. The heat flux meter system is formed by two heat flux sensors (Fig. 3a(I)), four superficial temperature sensors (Fig. 3a(II)), a data-logger (Fig. 3b) and a computer, and in accordance to [16]. The heat flux sensors enable to measure the heat flow across an element when there is a significant thermal gradient between its two surfaces (i.e. indoor surface and outdoor surface). The superficial temperature sensors were used as a complement and as a reference to the heat flux sensors, in order to measure the inner surface temperature of the corn cob particleboard sample. Two superficial temperature sensors by heat flux sensor were used, as shown in Fig. 3a. Meanwhile, in Fig. 3c 


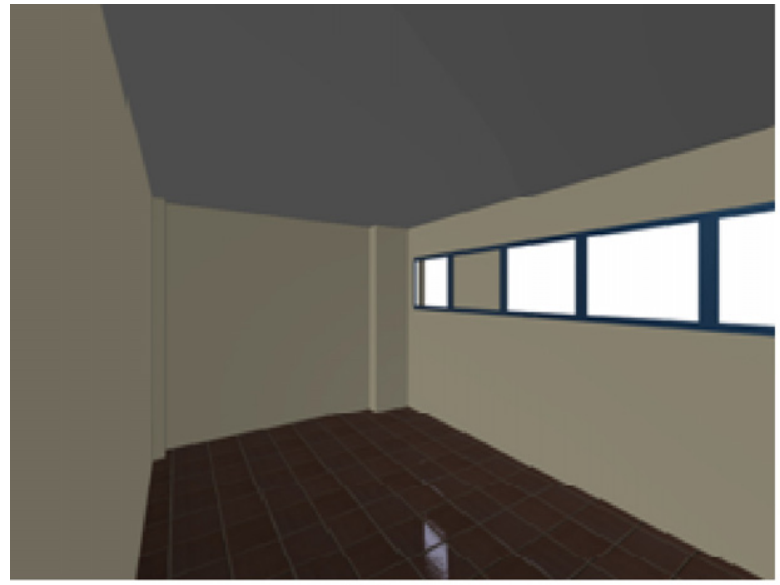

a) View 1

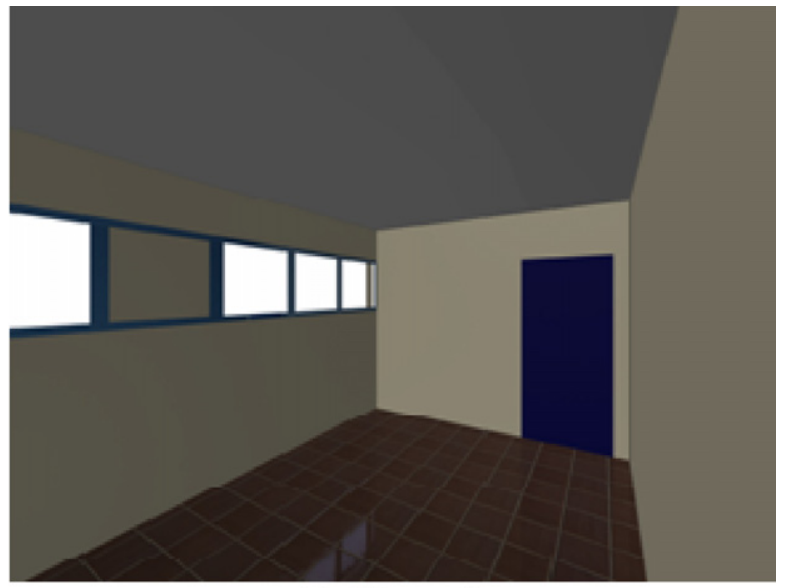

b) View 2

Fig. 2. Facility.

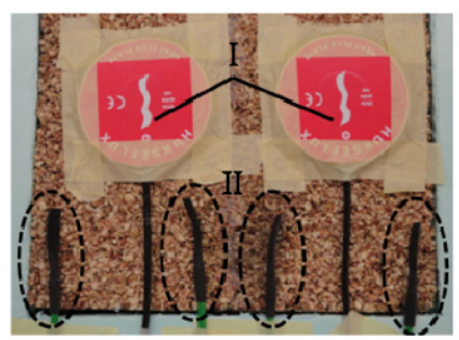

a) Heat flux (I) and superficial temperature sensors (II)

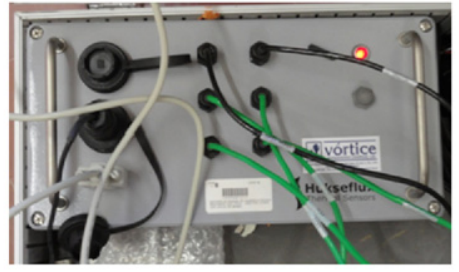

b) Data-logger

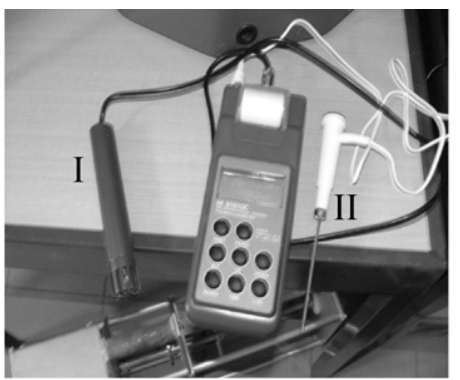

c) Thermo hygrometric device. Temperature (I) and relative humidity (II) sensors

Fig. 3. Equipment used

the adopted thermo hygrometric device which includes a temperature sensor (Fig. 3c(I)) and a relative humidity sensor (Fig. 3c(II)) is shown. As it was mentioned above, two thermo hygrometric devices were used, one to measure the temperature and humidity indoor and the other to measure the same parameters outdoor.

\subsection{Sample preparation}

Corn cob particleboard samples (Fig. 4(I)) sized $e \mathrm{~cm} \times 25 \mathrm{~cm} \times 25 \mathrm{~cm}$ (thickness $\times$ width $\times$ height) were processed in four different thicknesses such as $3 \mathrm{~cm}, 5 \mathrm{~cm}, 6 \mathrm{~cm}$ and $8 \mathrm{~cm}$. This range of thickness corresponds to the most available thicknesses of the currently applied thermal insulation products (e.g. XPS) in the Portuguese building industry context. The curing process occurred in the laboratory (i.e. under controlled thermal and hygrometric conditions) and the samples were completely dried during the tests. The average density of the corn cob particleboard samples was $334 \mathrm{~kg} / \mathrm{m}^{3}$. XPS panels (Fig. $4(\mathrm{II})$ ) sized $e \mathrm{~cm} \times 76 \mathrm{~cm} \times 64 \mathrm{~cm}$ (thickness $\times$ width $\times$ height) was used as a support of the corn cob particleboard samples in which the respective thicknesses are similar to the above identified ones. The size of the XPS support panel is similar to the size of an existing window of the confined room. A hole was done in the central area of the XPS panel shaped and sized similarly to the corn cob particleboard sample. The corn

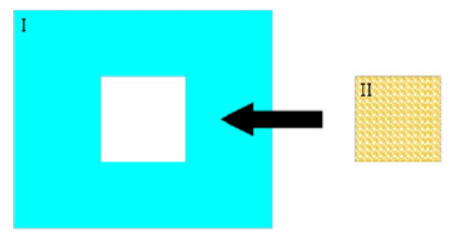

a) XPS and particleboard

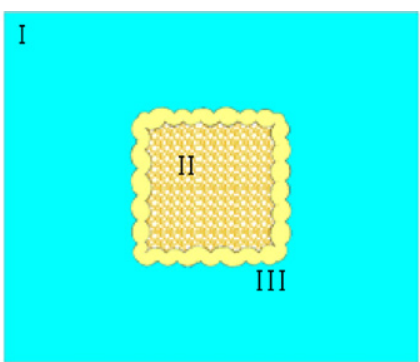

b) The two materials connected

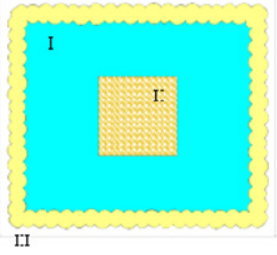

c) A window replaced by the set

Fig. 4. Sample preparation. 
cob particleboard sample is then placed in the hole of the XPS panel and both materials are connected by polyurethane foam which is applied from the outer face (Fig. 4(III)). The set (i.e. particleboard and XPS) replaces a window and it is also fixed by polyurethane foam applied from the inside this time as shown in Fig. 4c. All these experimental procedures have to be done carefully in order to avoid insulation voids, thermal bridges, non-insulated headers and other faults which may compromise the reliability of the final results. In Fig. 5 are shown a $3 \mathrm{~cm}$ and a $5 \mathrm{~cm}$ thickness corn cob particleboard samples being tested simultaneously and also can be featured the above described experimental set-up.

The heat flux sensors and the superficial temperature sensors were fixed on the inner face of the samples using adhesive tape and thermal glue according to Fig. 5 . This procedure is extremely important taking into account the rugosity of the surfaces of the corn cob particleboard. It is imperious to guarantee a perfect contact between the surfaces of the heat flux sensor and the inner face of the corn cob particleboard, in order to avoid any possibility of the sensors coming off during the test. According to ISO 9869 [16], the test duration should be related to the thermal inertia of the building element under study. For a high thermal inertia building element a fourteen-day test, at least, is recommended. On the other hand, for a low thermal inertia building element a minimum of $72 \mathrm{~h}$ (i.e. 3 days) test is recommended. For instance, a common external brick cavity wall with a $4 \mathrm{~cm}$ air box may be considered as having a high thermal inertia. The corn cob particleboard sample may be considered as having a low thermal inertia and therefore a minimum five day test was adopted in this case.

\section{Experimental results}

As it was mentioned earlier corn cob particleboard samples of thicknesses $3 \mathrm{~cm}, 5 \mathrm{~cm}, 6 \mathrm{~cm}$ and $8 \mathrm{~cm}$ were tested. These samples are shown in Fig. 6.

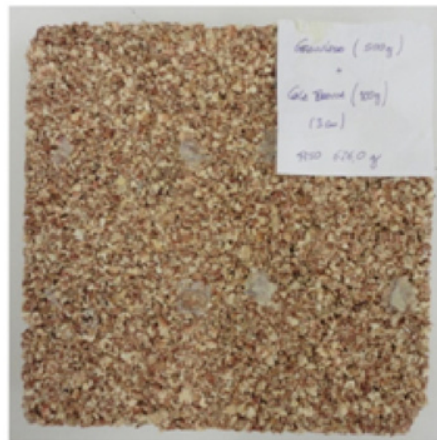

a) $3 \mathrm{~cm}$ panel

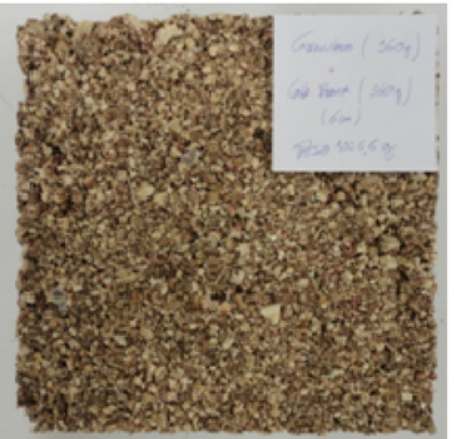

c) $6 \mathrm{~cm}$ panel
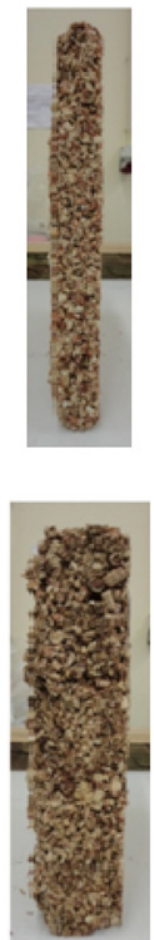

Fig. 6. Corn cob particleboard samples $(25 \mathrm{~cm} \times 25 \mathrm{~cm})$

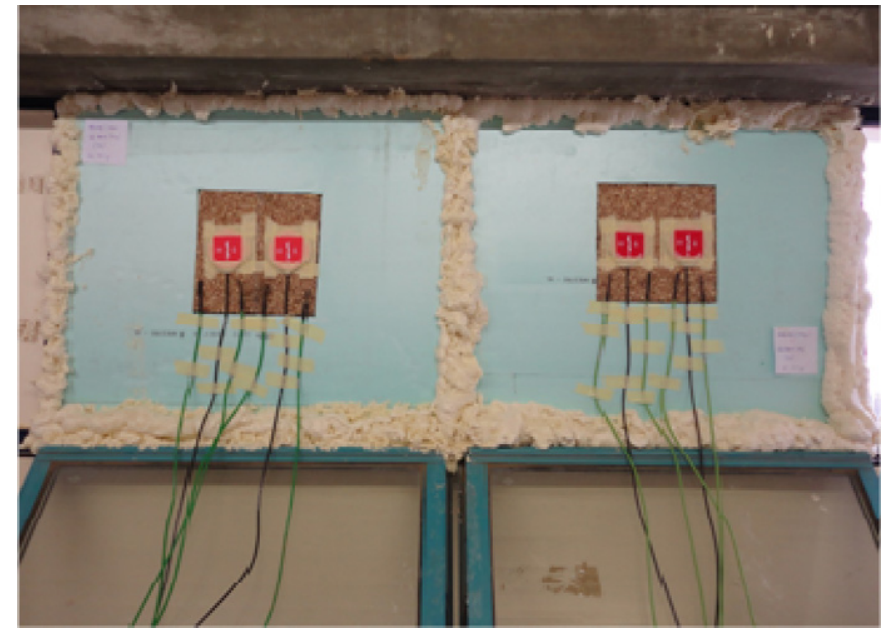

Fig. 5. Two samples being tested.

A continuous data acquisition during the tests was performed in which the values of the heat flow across the panel measured by the two used heat flux sensors ( $q 1(n)$ and $q 2(n))$, the interior and the exterior temperatures $(\operatorname{Ti}(n)$ and $\operatorname{Te}(n))$ and the relative humidity were registered at a $10 \mathrm{~min}$ timing interval each $(n)$. Figs. 7-10 represent graphically the above identified registered data for each panel sample experimentally analyzed. It can be noticed that the interior temperature of the confined room was kept almost uniform, at $22.9^{\circ} \mathrm{C}$ approximately, in all the cases. On the other hand, the exterior temperature showed the natural and the expected variation during a day, in this period of the year in the north region of Portugal. The exterior temperature was always lower than the interior temperature, and therefore there was no risk of occurrence of undesirable heat flow swapping across the sample. However, there was a moment, on 20th of March 2011, when the $6 \mathrm{~cm}$ thickness

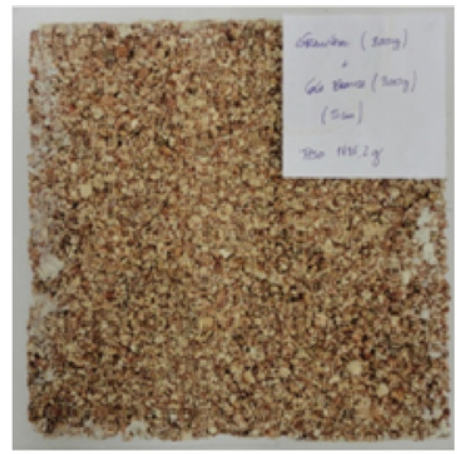

b) $5 \mathrm{~cm}$ panel

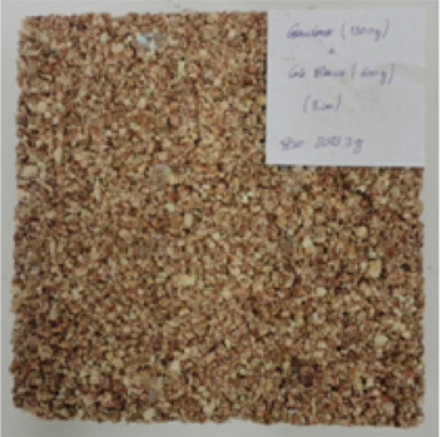

d) $8 \mathrm{~cm}$ panel
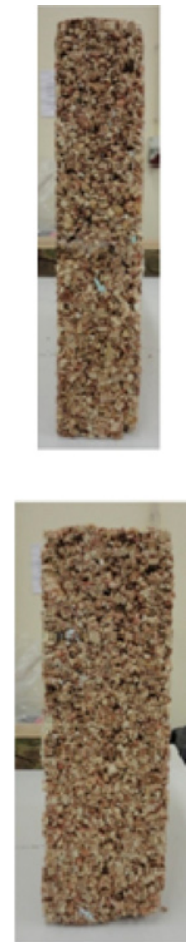


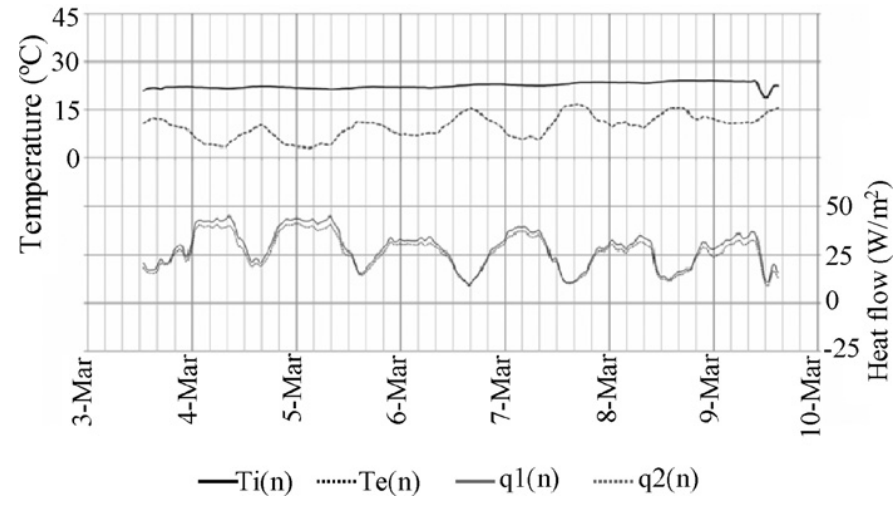

Fig. 7. Temperatures and heat flow related to the $3 \mathrm{~cm}$ panel. March (Mar) of 2011.

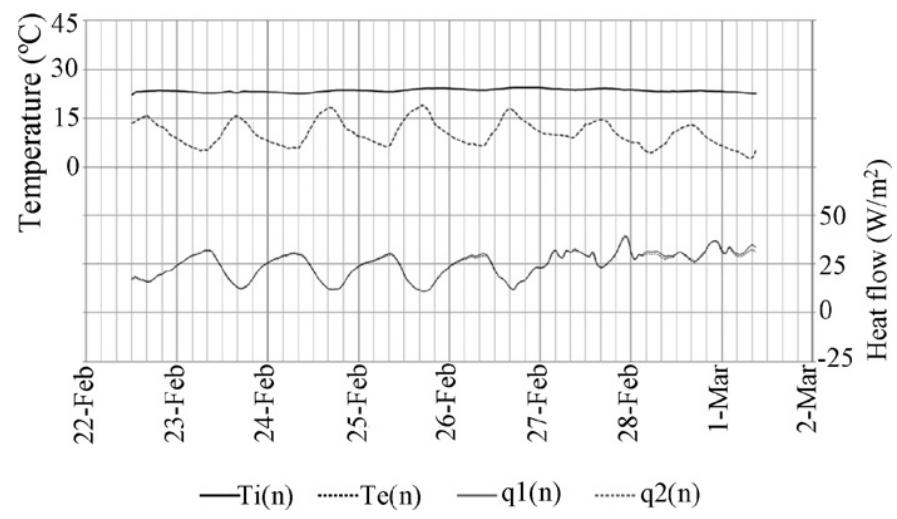

Fig. 8. Temperatures and heat flow related to the $5 \mathrm{~cm}$ panel. February (Feb) and March (Mar) of 2011.

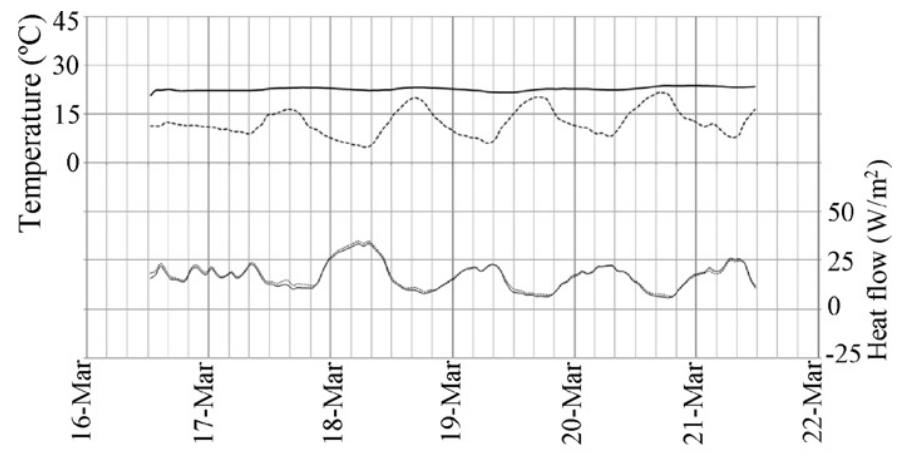

$-\operatorname{Ti}(n) \quad \cdots \cdots \cdot \cdot \operatorname{Te}(n) \quad-\mathrm{q} 1(\mathrm{n}) \quad \cdots \cdots \cdot \mathrm{q} 2(\mathrm{n})$

Fig. 9. Temperatures and heat flow related to the $6 \mathrm{~cm}$ panel. March (Mar) of 2011 .

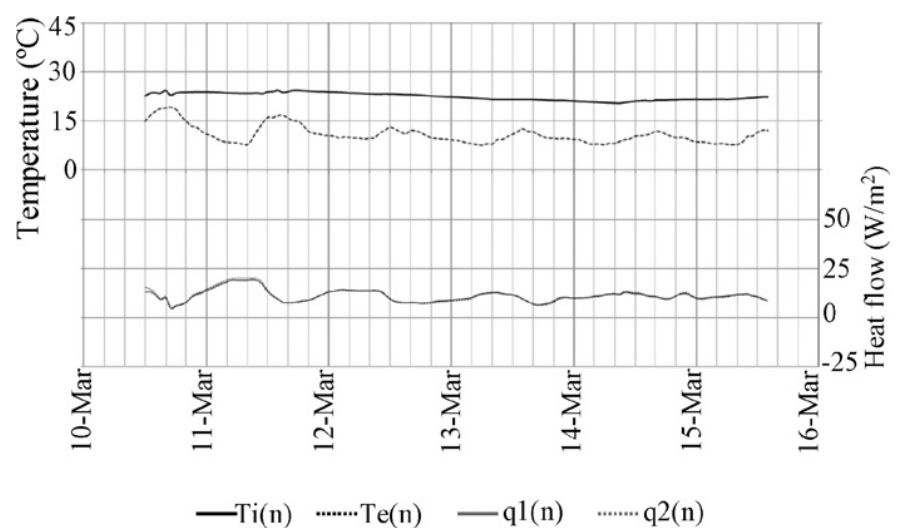

Fig. 10. Temperatures and heat flow related to the $8 \mathrm{~cm}$ panel. March (Mar) of 2011.
Table 1

Thermal transmission coefficient $\left(U^{\prime}(\right.$ ntotal $\left.)\right)$ of corn cob particleboards with different thicknesses.

\begin{tabular}{ll}
\hline Sample & $U^{\prime}($ ntotal $)\left(\mathrm{W} / \mathrm{m}^{2}{ }^{\circ} \mathrm{C}\right)$ \\
\hline $3 \mathrm{~cm}$ panel & 2.14 \\
$5 \mathrm{~cm}$ panel & 1.89 \\
$6 \mathrm{~cm}$ panel & 1.64 \\
$8 \mathrm{~cm}$ panel & 0.95 \\
\hline
\end{tabular}

corn cob particleboard sample was being tested, in which the exterior and interior temperatures almost reached the same value. It is also clearly noticeable that the heat flow peaks occurred in parallel with the peaks of the gradient of the interior and the exterior temperatures.

According to ISO 9869 [16], the thermal transmission coefficient $(U)$ can be quantified applying Expression (1).

$U($ ntotal $)=\frac{\sum_{n=1}^{n t o t a l} q(n)}{\sum_{n=1}^{\text {ntotal }}(\operatorname{Ti}(n)-T e(n))}$

In which: $U$ is the thermal transmission coefficient; $q(n)$ is the heat flow across the sample in the moment $n ; \operatorname{Ti}(n)$ and $\operatorname{Te}(n)$ are the interior and the exterior temperature in the moment $n$, respectively; ntotal is the total number of moments is which the data was registered.

Taking into account that two heat flux sensors are used corresponding to $q 1(n)$ and $q 2(n)$, it is possible to estimate two thermal transmission coefficients, U1(ntotal) and U2(ntotal), by applying Expression (1). Thus, the thermal transmission coefficient of each sample $\left(U^{\prime}(\right.$ ntotal $\left.)\right)$ is the average value of $U 1$ (ntotal) and $U 2$ (ntotal), according to Expression (2).

$U^{\prime}($ ntotal $)=\frac{U 1(\text { ntotal })+U 2(\text { ntotal })}{2}$

In which: $U^{\prime}$ (ntotal) is the thermal transmission coefficient of the sample; U1(ntotal) and U2(ntotal) are the thermal transmission coefficient related to the data registered by the heat flux sensors 1 and 2 , respectively.

Based on the above presented experimental data (Figs. 7-10) and applying the previous expressions it is possible to estimate the thermal transmission coefficient of the different corn cob particleboard samples which are presented in Table 1.

The increasing thickness of a corn cob particleboard benefit in terms of thermal insulation performance, which is clearly evident by the thermal transmission coefficients presented in Table 1 and it corroborates the suggestion made by Dowling and Mathia [12], concerning the improvement of the thermal insulation performance of products based on corn cob material.

\section{Discussion}

The thermal conductivity $(\lambda)$ of a material can be quantified by knowing its thermal transmission coefficient. Therefore, a $0.101 \mathrm{~W} / \mathrm{m}^{\circ} \mathrm{C}$ value of the thermal conductivity for the corn cob particleboard was estimated. Taking into account that the respective value of XPS and expanded polystyrene (EPS) is approximately $0.037 \mathrm{~W} / \mathrm{m}^{\circ} \mathrm{C}$ and $0.045 \mathrm{~W} / \mathrm{m}^{\circ} \mathrm{C}$, respectively according to [17], the studied particleboard has shown a disappointingly low thermal insulating performance. However, considering that XPS and EPS are already established commercial industrialized products, the particleboard was manufactured using a natural organic material whose process is still in progress, and the obtained thermal conductivity value for the corn cob particleboard is still acceptable in terms of thermal insulating building purposes, there are undoubtedly strong reasons to believe that the analyzed alternative product is promising in a thermal insulating perspective. 
The thermal insulation performance of an XPS sample (i.e. (I) in Fig. 4) was also experimentally analyzed according to the above proposed and described procedure, and during the same period of the year 2011. A value of $0.043 \mathrm{~W} / \mathrm{m}^{\circ} \mathrm{C}$ of thermal conductivity was obtained which is slightly higher than the $0.037 \mathrm{~W} / \mathrm{m}{ }^{\circ} \mathrm{C}$ indicated in [17] (i.e. 14\% higher) but still approximated. This difference may be related to operational errors which may include several aspects such as: the fact that the test was performed in situ rather then in a thermal testing cell; the equipment precision; the data acquisition; that a representative amount of XPS samples was not considered; among other aspects. Meanwhile, [16] considers a maximum admissible error of $20 \%$ (i.e. higher than $14 \%$ ). Thus, this fact may lead us to the conclusion that the proposed experimental set-up which uses a confined room instead of a thermal testing cell for evaluating the thermal insulation performance of corn cob particleboard may be adequate.

The connection between the corn cob particleboard sample and XPS support panel, the fixation of the set (i.e. corn con particleboard inserted in the XPS support panel) in the window frame and the respective sealing up, the uncontrolled exterior temperature variation, the contact between the surfaces of the heating transfer sensor and the inner surface of the corn cob particleboard sample and the equipment calibration are also additional technical aspects which may affect the accuracy of the proposed experimental set-up.

\section{Conclusions}

An alternative expedite experimental set-up based in ISO 9869 [16] was proposed to evaluate the thermal insulation performance of corn cob particleboard. In brief, it consists of using a confined room able to guarantee a constant interior temperature and having a window, working as an alternative solution for a thermal test cell. The particleboard sample is inserted in an XPS support panel and the set replaces a window. A heat flux meter system formed by two heat flux sensors, four superficial temperature sensors, a data-logger and a computer is adopted to measure the heat flow across the sample and the superficial temperature of the inner surface of the sample. In parallel, thermo hygrometric sensors placed in the interior and the exterior allow the measuring of the respective interior and exterior temperatures and relative humidity. Since the material under study was corn cob particleboard, considered as having a low thermal inertia, a five days test was adopted. This proposed experimental set-up proved to be accurate, made it possible to perform thermal insulation performance tests under real thermal and hygrometric conditions, in situ, to use more realistic sample dimensions, to test more than one sample at the same time and to monitor the thermal behavior of a product continuously for several days. Technical aspects related to the connection between the corn cob particleboard sample and the XPS support panel, the fixation of the set (i.e. corn cob particleboard inserted in the XPS support panel) to the window frame and the respective sealing up, and the perfect contact between the surfaces of the heat flux sensor and the inner surface of the corn cob particleboard sample need to be done carefully in order to avoid undesirable thermal condition faults. In the Portuguese north region context, this experimental methodology is more adequate to carry out during the winter or the summer seasons in which it is more reliable to ensure the desirable significant thermal gradient between indoors and outdoors. Through this experimental methodology it was possible to do a parametric study of the corn cob particleboard in which the impact of the thickness of the panel in its thermal insulation performance was verified. Thicker corn cob particleboard has small thermal transmission coefficient corroborating the suggestions made by Dowling and Mathia [12]. Finally, the proposed alternative expedite experimental set-up can be easily adopted for the thermal insulation performance study of other alternative sustainable engineered materials or products.

\section{References}

[1] J. Younquist, B. English, H. Spelter, P. Chow, Agricultural fibers in composition panels, in: Proceedings of the 27th International Particleboard/Composite Materials Symposium, 30-31 March, Pullman, Washington, 1993, pp. 133-152.

[2] P. Chow, Dry Formed Composite Board from Selected Agricultural Residues. World Consultation on Wood Based Panels, Food and Agriculture Organization of the United Nations, New Delhi, India, 1974.

[3] P. Lertsutthiwong, S. Khunthon, K. Siralertmukul, K. Noomun, S. Chandrkrachang, New insulating particleboards prepared from mixture of solid wastes from tissue paper manufacturing and corn peel, Bioresource Technology 99 (2008) 4841-4845.

[4] J. Khedari, N. Nankongnab, S. Fotios, Agricultural waste materials as thermal insulation for dwellings in Thailand: preliminary results, in: PLEA 2008: 25th Conference on Passive and Low Energy Architecture, 22-24 October, Dublin, Ireland, 2008.

[5] N. Stone, Thermal performance of straw bale wall systems, Ecological Building Network (EBNet) (2003) 1-7.

[6] N. Soon-Ching, L. Kaw-Sai, Thermal conductivity of newspaper sandwiched aerated lightweight concrete panel, Energy and Buildings 42 (2010) 2452-2456.

[7] C. Hasse, M. Grenet, A. Bontemps, R. Dendievel, H. Sallée, Realization, test and modeling of honeycomb wallboards containing a phase change material, Energy and Buildings 43 (2011) 232-238.

[8] N. Quaranta, M. Caligaris, H. López, M. Unsen, N. Lalla, M. Franzoy, M. Carrasco, J. Cotroni, M. Avendaño, Addition of polymeric wastes as pore formers in ceramic lightweight bricks, Transactions on Ecology and the Environment 128 (2010) 447-458.

[9] J. Pinto, A Paiva, H. Varum, A Costa, D Cruz, S. Pereira, L Fernandes, P. Tavares, J. Agarwal, Corn's cob as a potential ecological thermal insulation material, Energy and Buildings 43 (2011) 1985-1990.

[10] J. Guan, M. Hanna, Functional properties of extruded foam composites of starch acetate and corn cob fiber, Industrial Crops and Products 19 (2004) 255-269.

[11] S. Panthapulakkal, M. Sain, Agro-residue reinforced high-density polyethylene composites: fiber characterization and analysis of composite properties, Composites Part A 38 (2007) 1445-1454.

[12] A. Dowling, J. Mathia, Experimental determination of the insulating ability of corn by-products, Journal of Sustainable Agriculture 30 (2) (2007) 15-27.

[13] D. Adesanya, A. Raheen, Development of corn cob ash blended cement, Construction and Building Materials 23 (2009) 347-352.

[14] J. Pinto, A. Paiva, A. Costa, P. Tavares, L. Fernandes, A. Murta, H. Varum, Building with sugar and corn, in: Advances in Production Management Systems APMS2010 Competitive and Sustainable Manufacturing Products and Services, 11-13 October, Cernobbio, Como, Italy, 2010.

[15] ANPROMIS, Associação Nacional dos Produtores de Milho e Sorgo, Available at: http://www.anpromis.pt/.

[16] ISO 9869, Thermal Insulation: Building Elements - In Situ Measurement of Thermal Resistance and Thermal Transmittance, International Organization for Standardization (ISO), 1994.

[17] C. Santos, L. Matias, Coeficientes de Transmissão Térmica de Elementos da Envolvente dos Edifícios, ITE 50, Coleção Edifícios, LNEC, Lisbon, 2006. 